\title{
The Exploration of Cultivating Mode of Engineering Students' Innovation Ability
}

\author{
Wang Yongqi ${ }^{1, a}$, Yang Yang ${ }^{2, b}$ \\ ${ }^{1}$ College of Electronic and Electrical Engineering, Shanghai University of Engineering Science, 333 \\ Longteng Road, Songjiang District, Shanghai, China \\ ${ }^{2}$ Advanced Vocational Technical College, Shanghai University of Engineering Science, 88 Yixian \\ Road, Hongkou District, Shanghai, China \\ awangyongqi17008@163.com, byydaisy@163.com
}

Keywords: Engineering Majors, Innovation, Cultivating Mode

\begin{abstract}
In this paper, combined with the characteristics of students in local engineering universities and professional educational goals, through teaching program setting, teaching reform, university students innovative projects and university-enterprise co-cultivating mechanism, we explore the innovation ability cultivating mode of diversification talents during engineering major construction and propose reasonable suggestions for the cultivating.
\end{abstract}

\section{Introduction}

President Xi Jinping points out at the opening ceremony of the Seventeenth Chinese Academy of Sciences, 'Innovation causes call for innovative talents. If China wants to lead the world in science and technology innovation, China must discover talents in innovation practice, nurture talents in innovative activities and agglomerate talents in innovation causes, and must vigorously cultivate large-scale, reasonable structure, high-quality innovative talents.'

For local universities as teaching oriented, their aim is to train applied talents and their main task is to develop application-oriented and some compound talents which are needed for regional economic and social development. At present, talents can be divided into four types, which are academic, engineering, technology-based and skill-based, while application-oriented universities actually contain engineering and technical education. Among these, engineering talents can apply the scientific principles and professional knowledge into the engineering field and make design scheme and design drawings for projects; while technology-based talents can solve those technical problems during the process of turning the design scheme and design drawings into products to be large-scale manufactured. If these two types of talents are trained by more advanced technology education and more innovative drills, and they can engage in new technical product developing after graduation, then they would be compound talents. Clearly, conducting innovation training in local universities is an effective way to train applied innovation talents. Through systematic training, students' engineering awareness and engineering quality will be cultivated, and their practical ability and innovation ability will be improved.

Thus, actively exploring innovation ability cultivating mode of science and engineering undergraduates has very important significance. This paper discusses the collaborative innovation system through teaching program setting, teaching reform, students' innovation activities and university-enterprise cooperation, preliminarily explores the innovation ability cultivating mode of science and engineering students, which is uniquely played by universities in the national innovation development.

\section{The Status Quo Analysis of Students’ Innovation Ability}

With the increasing number of college students, they are educated in large classes. Traditional classroom teaching methods are difficult to provide effective and innovative thinking training to 
college students, which make them general lack of innovation ability[1]. Thus there are many urgent innovation education problems to be solved in university education.

Lack of Innovative Ideas and Concepts. Many college students just like to complain about the situation. They have grandiose aims but puny abilities, are unwilling to active learning, only want to pass the exam, do not want to be innovative, and even they do not have the confidence of innovation. Lack of Innovative Methods. Some of the students also want to be able to innovate, but do not know how to innovate. They are weak in intuitive thinking, logical thinking, divergent thinking, reverse thinking, associative thinking, and are needed for specialized training [2].

Lack of the Perseverance of Innovation. Some of the students have recognized the importance of innovation, and also have innovative ideas, but due to the lack of willpower it is hard for them to persevere. If it is difficult to reach the target, they are often easily to give up halfway.

Lack of Innovation Practices. The university offers few opportunities for innovation and few guides for cultivation of the interest of innovation consciousness. College students generally lack innovative practical projects and support force, even if they do need them.

\section{The Existing Problems in the Innovation and Practice Ability Cultivating Mode of Engineering Students}

Lack of Innovation in Teaching Contents and Teaching Methods. The talents cultivating mode of many local engineering universities is influenced by traditional educational ideas and concepts, which restricts the cultivating of engineering students' innovation ability to a large extent. Teachers only focus on theoretical knowledge instilling, and ignore cultivating the students' practical ability. Students are passive learners, which limits the training of students' critical thinking and dialectical thinking[3]. So, engineering students form a thinking mode of 'More attention to theory and research, less attention to practice', which greatly confines the initiative and innovation of students.

Unreasonable Course System. The engineering universities majors are divided too narrowly, which isolates professional knowledge, results in narrow professional caliber, and lacks multi-type and diversity. The compulsory courses prescribed by university are too many, and the selective courses are relatively small. The design of practical teaching plan is often disjointed with engineering practice, and lecture hours are arranged at the end of semester and are separated from theoretical teaching, which is not a good engineering practice mode. The space and time of students' independent learning is greatly confined. Students can only focus on activity in the narrow discipline platform, which is not good for interdisciplinary and major development, limits students horizons, and affects the cultivating of the students' innovation ability.

Lack of Evaluation and Incentives. At present, most of the engineering universities generally lack the evaluation and incentive mechanism for students' innovation ability. The appointing and evaluating of university teachers only focuses on the quality and the number of scientific research projects and papers, without clear quantitative requirements of the innovation ability cultivating of students, so teachers' enthusiasm and initiative in training innovation talents are affected[4,5]. Meanwhile, the test mode of engineering students can not only focus on the assessment of theoretical knowledge, while ignore the test for students to participate in community activities, in social practices and research activities. So, students can not enjoy the sense of accomplishment and the sense of worth of innovation activities, which leads to the lack of passion and persistence of students for innovation.

Therefore, we should actively carry out the research in innovation ability cultivating mode of engineering students, review and sort out approaches, like, changing teaching idea, conducting student training in science research, reforming assessment and incentives, and cultivating humanity quality, to enhance the innovation ability of engineering students. 


\section{Cultivating Measures for Engineering Students’ Innovation Ability}

Setting Innovation Credits in Teaching Programs.Innovation credits are set in the teaching programs of our university, which requires students to obtain at least 4 credits of innovation through the research training program, various lectures reflecting frontier developments, as well as various professional competitions and other innovation activities. To prevent increasingly utilitarian and short-term benefit in innovation research, our university establishes and implements the 'innovation credits' quality assurance system, improves various monitoring mechanisms, and guarantees the quality of innovation credits through a full range of regulations.

Education System Reform. University should cultivate the campus cultural environment and academic atmosphere to adapt to the innovation and practical ability of students. Teachers should change the traditional teaching mode in the teaching process, combine academic lectures with classroom teaching, focus on the cultivation of students' personality, and explore the potential of students. Student learning assessment should focus on examining the ability of students. The participation in research activities is proportionally included in the assessment of student achievement, to enhance students' initiative to research activities and promote practical ability and innovation capability.

Carrying out Students Research Training. Most of our engineering university have set up all kinds of university students' innovation research training programs to guide the students to participate in scientific research activities, and cultivate the spirit of innovation and research interests. Instructor distributes the research tasks correspondingly. The innovation team members gather information, consult literatures, make plan around each one's sub-task, analyze the experimental results using their expertise, and discuss research progress in the research team regularly every week. Finally, research innovation team uses the researching results to apply for research fund from university administration, publish papers or patents, and acquire credits and reward.

Actively Set up All Kinds of College Students Innovation Team, Expand the Innovative Perspective of College Students. Oriented to some students, we actively encourage all kinds of innovation team based on the major characteristics, carry out all kinds of activities aiming to popularize the innovation education, such as, academic salon, student culture festival, academic forum, etc., to help the student improve the breadth of knowledge and expand their professional horizons. In the face of the current cross integration of various disciplines, we propose a wider range of innovation topics and strive to practice, with the aim to cultivate the students expanding the field of innovation and paying attention to the concept and spirit of teamwork. Following aspects are needed to be focused: (1) the formation of innovation team, is based on the research direction of our teachers and the current research hotspot, and the students who are interested in with the direction can choose the teacher, and the teacher can also choose the students; (2) the operation mechanism and mode should meet the characteristics of our university, and should be administered and evaluated; (3) Organize the undergraduate innovation forums and competitions to accumulate experiences. Then, team building, team activities can be observed to evaluate students' innovation ability, and can also be used as a basis for innovation credits.

Formulate Relevant Policies for Research Teaching System. Research teaching and innovation talents training can not be separated from related policy support, such as, the students' employment evaluation, teachers' teaching performance evaluation, etc. Formulating the index system which reflect the research teaching effect, can fully evaluate the teachers' teaching and students' innovation thinking ability. The single traditional talents cultivating mode can not reflect the real level of students, and is not conducive to the innovation talents training. Students ability evaluation index should be diversified, such as, taking part in the project, operating experiments, writing papers, participating in the social investigation, participating in research projects, etc., to comprehensively survey the students' actively learning ability and innovation ability. Establishing the incentive mechanism to encourage students to innovate. Combine the research teaching of teachers and the 
innovative learning of students'. Give the students' innovation award for their innovation behavior and innovative results.

Enhancing Students' Innovation Ability through University-Enterprise Cooperation. In those European countries with top rank of global competitiveness, their universities of applied sciences as the main body of national education, play an important role in cultivating high-quality technical talents, enhancing nation competitiveness, promoting industrial upgrading and transformation, and university-enterprise co-operations also play a positive role[6]. Chinese universities should learn from this experience, deepen cooperation with enterprises, widely establish practicing base outside the university. Through corporate practice and exercise, combining theoretical knowledge with actual production, students will have more profound understanding of the professional knowledge, improve their comprehensive ability, such as learning ability, judgment ability, integration ability and innovation ability, and cultivate their innovation ability.

\section{The Results of Our Reform}

Through a series of reforms, we achieved gratifying results, mainly in the following areas:

Students Innovation Ability Is Strengthened with Outstanding Performance in All Kinds of Competitions. Through a series of reform measures, with the strengthened students' innovation ability, in the past three years our engineering students participated a total of 280 innovation and entrepreneurship projects at national level, provincial level and university level, among these, 115 projects are awarded at provincial level and above. And 8000 people attended our teachers' open experiments.

Teachers' Engineering Practice Ability Has Been Strengthened with Remarkable Teaching Achievements. During the course of the construction of comprehensive reform pilot program, the teacher's initiative is mobilized. In the past three years, young teachers got 60 awards in skill contest activities at university level; there are 20 groups of students received awards in electronic design contest at the provincial level or above guided by our teachers; 15 teachers as the main members received teaching achievement awards at province level or university level.

\section{Summery}

Students' cultivating mode can be optimized, and also should keep up with the times. Universities should keep the pace with the times, strengthen connection with other institutions, constantly adjust and optimize the cultivating mode to train qualified talents for the society. It is the students' needs, the need of the times, and also the needs of the development of university itself.

\section{References}

[1] Wei Yan, Yunsong Yuan: Exploration and Practice of the Cultivation of College Students' Innovation Ability. Teaching in Chinese Universities, Vol.9(2012), p.78

[2] Jian Lin: Pay Great Attention to the Essence of Excellent Engineering Education, Innovate the Engineering Personnel Training Mode. Higher education in China. Vol.6(2011), p.19

[3] Yiyu Cao, Lan Xiao: Cultivation of College Students' Scientific and Technical Abilities. Journal of Hunan Institute of Science and Technology. Vol.29(2008), p.221

[4] Yangfan Li, Xiaodong Zhu: Research Training Program and Cultivation of College Students' Innovation Abilities. China University Teaching. Vol.4(2011), p.24

[5] Guangshun Wang, Xiaolei Chen: On College Students' Research Ability and Training Ways. Journal of Hebei Normal University. Vol.11(2006), p.95 
[6] Feng Jiang: University of Applied Sciences - Cradle of German Engineers. China Education Daily, 2014 